\title{
Human Cancer Pathology
}

National Cancer Institute

\section{Source}

National Cancer Institute. Human Cancer Pathology. NCI Thesaurus. Code C19746.

The branch of pathology concerned with the cause, origin, and nature of human cancers. 